\title{
Silva Bratož
}

University of Primorska

Faculty of Management Koper

\section{A Stylistic Analysis of Four Translations of J. D. Salinger's The Catcher in the Rye}

\begin{abstract}
Summary
The paper looks at stylistic differences between four translations of J. D. Salinger's Catcher in the Rye - two Slovene translations, a Serbo-Croatian, and an Italian translation. Firstly, stylistic components relevant to the novel in question are identified. In this respect, the translation of teenage speech and idiom appears to be not only the most conspicuous stylistic feature of the original but also the hardest to translate. Secondly, the ways in which the different translations have rendered certain formal and lexical features of style are compared by determining and describing their function. A large number of examples have been submitted to critical scrutiny, of which only a few representative ones are listed and explained in the paper. Finally, this paper points to some particular difficulties of the four translators in their attempts to reproduce the stylistic components of the original.
\end{abstract}

\section{Slogovna analiza štirih prevodov romana The Catcher in the Rye J. D. Salingerja}

\section{Povzetek}

Prispevek obravnava slogovne razlike med štirimi prevodi J. D. Salingerjevega romana The Catcher in the Rye, in sicer med dvema slovenskima, italijanskim in srbohrvaškim prevodom. Gre predvsem za primerjalno analizo funkcije osrednjih slogovnih prvin med prvotnim besedilom na eni ter omenjenimi štirimi prevodi na drugi strani. Primerjava se osredotoča zlasti na tiste slogovne značilnosti, ki so posameznim prevajalcem pri prevajanju $\mathrm{v}$ omenjene tri jezike povzročale težave. $\mathrm{V}$ prispevku ugotavljam, da se prevodi razlikujejo predvsem pri prevajanju slengovskega jezika, ki po mnenju Salingerjevih kritikov predstavlja osrednjo slogovno značilnost romana. 


\section{A Stylistic Analysis of Four Translations of J. D. Salinger's The Catcher in the Rye}

\section{Introduction}

Few novels in contemporary American literature have aroused so much admiration, imitation and controversy as J. D. Salinger's The Catcher in the Rye. It has been considered by many an established classic, by others a dated piece of sentimentality. Most interesting of all, immediately after its publication it was attacked and banned as immoral due to its crude, profane and obscene language. However, despite the protests from school authorities (among others), the novel immediately won the admiration of those about whom it was written. College students have imitated and idolized the rebellious and dissatisfied hero, Holden Caufield, whose threeday odyssey is chronicled in The Catcher in the Rye. Today the novel is no longer regarded as a threat to immature teenagers. It is studied and discussed in schools as an important literary achievement and has been translated and retranslated into a number of languages.

It also stands out as one of the few modern novels that have been translated into Slovene twice. This is nothing unusual if we consider the wealth of translations of major writers, such as Homer, Baudelaire, Goethe or Shakespeare. New translations of already translated work appear every day, but why would we need a new translation if the original always remains the same and is read as such. Meta Grosman (1987) points out that every translator is foremost a reader of the text and as a reader their interpretation is temporally, culturally and socially determined, which also explains why a translation is meant primarily for the contemporary reader and why it becomes old and less interesting for future generations. Moreover, by exploring alternative translations of the same work, we are able to compare different interpretations of the text and translation solutions employed by various translators. In this regard it is also worth considering and contrasting translations of a text in different languages (Grosman 1997). I will try to show how this may prove especially beneficial in analysing the issue of style.

The present paper looks at four translations of the novel, i.e. two Slovene, an Italian and

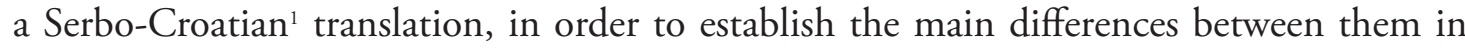
terms of style. Firstly, stylistic components relevant to the novel in question are identified. Secondly, the ways in which the different translations have rendered certain formal and lexical features of style are compared. The comparison focuses on determining and discussing the function of the various stylistic features of the four translations in relation to the original text. In this respect, I will point out some particular difficulties faced by the four translators in their attempt to reproduce, consciously or unconsciously, the stylistic features of the original.

${ }^{1}$ At the time when this translation was published, Serbo-Croatian was one of the official languages in the former Yugoslavia and has now been replaced by two independent languages, namely Serbian and Croatian. 
In her case study A Methodological Proposal for the Assessment of Translated Literary Work Garces proposes a method for the comparison of different translations of the same work which considers four linguistic levels, levels which are inter-related in the whole process of translation: semantic-lexical, syntactical-morphological, discoursal-functional and stylisticpragmatic (Garces 1994, 78-9). Different translation techniques can be used at each level, depending on the work studied. However, boundaries between the four levels are often difficult to determine, which means that the relevant techniques could be placed on different levels at the same time. As I am aware that the notion and definition of style may embrace all kinds of textual and contextual elements (see Hatim 1997), I shall limit the choice of stylistic components discussed below to some particular uses of language pertinent to the novel in question.

\section{Bibliographic Data}

The original American edition was first published in book form in 1951; the copy used in this paper is a 1994 reprint published by Penguin Books. The first Slovene translation was made by Milka Mirtič-Saje (M-S) and published by Mladinska knjiga in 1966 (9800 copies). The second Slovene translation, made by Boris Jukić (J), was also published by Mladinska knjiga in 1990 (2600 copies). The Serbo-Croatian translation was published by Beogradski izdavačkografički zavod in 1987 and was translated by Dragoslav Andrić (A). Published by Einaudi in 1961, the Italian translation was made by Adriana Motti (M) and has remained the only translation in Italian so far.

\section{Critical Response}

In order to establish and identify the predominant stylistic features of the novel it is necessary to look at some critical comments which have marked the book's fate since its publication. In defence of its language, Edward P. J. Corbett wrote ten years after its publication in book form: "Considered in isolation, the language is crude and profane. It would be difficult to argue, however, that such language is unfamiliar to our young people or that it is rougher than the language they are accustomed to hearing in the streets among their acquaintances... Given the point of view from which the novel is told, and given the kind of character that figures as the hero, no other language was possible. The integrity of the novel demanded such language" (Belcher and Lee 1962, 55).

Holden Caufield has been compared to other heroes in contemporary literature, especially to Huckleberry Finn, whom Edgar Branch regards as Holden's 'brother under the skin'. Although Holden has a more educated vocabulary and, unlike Huck, knows how to spell, they both use a special vernacular to respond to the social and moral realities of their time. Or as Branch puts it "Holden is truly a kind of latter-day, urbanized Huck" (ibid., 26). 


\section{The Issue of Style}

Analysing translations in terms of style requires much more than simply listing stylistic features or identifying some stylistic devices or forms of the text in question. As Nida and Taber point out, the analyst of style must also endeavour to describe the significance of such features. This functional approach to style can help us understand something of the purposes of style. Nida and Taber divide these purposes (or functions) into two categories: (1) those which serve to increase efficiency and (2) those which are designed for special effects, i.e. enhance interest, increase impact, or embellish the form of the message (Nida and Taber 1982, 145-52). Bassnett argues that the process of translation may involve discarding the basic linguistic elements of the SL text so as to achieve 'expressive identity' between the SL and TL texts, or, in other words, to achieve stylistic equivalence, where there is functional equivalence of elements in both original and translation (Bassnett 1991, 25). In their attempt to reproduce the stylistic elements of the original text, translators should be aware of and translate accordingly all the particular uses of language, thus retaining the aesthetic factor in translation.

Holden, the hero of The Catcher in the Rye, expresses his relationship to other people and the world in general through the language he uses - a mixture of the typical teenage speech of his generation and strong personal idiosyncrasies. This is a significant stylistic feature of the novel and provides a valuable insight into the hero's personality. After all, the whole novel is Holden; we see everything through his point of view, so it is understandable that the style should represent an aspect of his character. In order to reproduce the language of the original as closely as possible, the four translators did indeed try to reproduce the language of an average teenager in their own languages. The examples below will show, however, that the translation of teenage slang and idiom was undoubtedly one of the most difficult aspects in translating this particular novel. This issue was also addressed by Mozetic (1997), who sees the translation of particular uses of language (substandard linguistic phenomena) as one of the weakest points in translating literature into Slovene and one of the least explored areas in the Slovene translation theory.

\section{Stylistic analysis based on the comparison of the four translations}

(a) Donald P. Costello has pointed to some typical stylistic features which are reflected in the language of the novel. First of all, Holden ends his thoughts with a loosely dangling 'and all' and its twins 'or anything', 'or something' and 'and stuff, and in Costello's words "uses them to such an overpowering degree that they become a clear part of the flavour of the book; they become more a part of Holden himself, thus contributing to his characterization. They serve no real, consistent linguistic function. They simply give a sense of looseness of expression and looseness of thought" (Belcher and Lee 1962, 45-59). In J's translation 'and all' and its twins are translated as in sploh, in vse to, in to, in drugo, and ali kaj jaz vem. The Serbo-Croatian translation is fairly consistent in translating 'and all' and its variants with ili tako nesto (ili tako nečega and other case forms) or i/ili slično, while the Italian translation sometimes directly translates 'and all' into e tutto. As for other variants of 'and all', the Italian translator decided to 
use a variety of Italian expressions which indeed express a certain looseness of thought in their own right, such as e via discorrendo, o vattelapesca, o di che so io, e cosi via, e tutto quanto, and eccettera eccettera to name but a few. In the first Slovene translation in tako dalje, in vse drugo are the most frequent translations of 'and all', but in most cases they are omitted. However, in the case of 'and stuff' and 'or something' $\mathrm{M}-\mathrm{S}$ seems to have misinterpreted their voidness of meaning, as the examples will show:

ST: “...We'd have to go downstairs in elevators with suitcases and stuff...” (119).

M-S: “...Morala se bova peljati navzdol v dvigalu s kovčki in služinčadjo...” (125).

ST: "... with his mouth full of mashed potatoes and peas or something." (17).

M-S: “...s polnimi usti pire krompirja ali testa." (22).

The back translation test shows that in English služinčad would be 'servants' and testo would be 'dough', which clearly indicates that the translation is overloaded with a semantic weight not contained in the original.

(b) The structure of Holden's sentences indicates that Salinger thinks of the book more in terms of spoken language than written language. This can be seen in a number of repetitions (e.g., "What would he do to me? I mean what would he do to me?", 133), afterthoughts (e.g., "It has a very good academic rating, Pencey.", 7) as well as in the accentuation of some words, or even parts of words, which are italicized, imitating the rhythms of speech as in: "He didn't even use his handkerchief. I don't even think the bastard had a handkerchief, if you want to know the truth" (30). Costello points out that Salinger, in his attempt to create a realistic character in Holden, wanted to make him aware of his speech, which is found in his habit of direct repetitions and repetitions of certain lexical items:

\section{Example 1}

ST: She was smart even when she was a very tiny little kid. When she was a very tiny little kid, I and Allie used to take her to the park with us, especially on Sundays. (...) Sometimes you'd forget she was around, because she was such a little kid, but she'd let you know (61).

M-S: Bila je pametna celo, ko je bila še prav majcen otrok. Ko je bila še prav majcen otrok, sva jo z Alliem vodila v park, posebno ob nedeljah. (...) Včasih si pozabil, da je poleg, ker je bila tako majcen otrok, pa te je opozorila nase (67).

J: Bistra je bila že, ko je bila čisto drobcena fakinka. Ko je bila še drobcena smrklja, sva jo z Alliejem večkrat peljala v park, zlasti ob nedeljah. (...) Zgodilo se je, da ste gladko malo pozabili, da je poleg, ker je bila taka frkljica, vendar vas je ona opozorila (66).

A: Bila je oštroumna još kad je bila detence. Kad je bila detence, ja i Ali smo je izvodili u park, naročito nedeljom. (...) Neki put bismo i zaboravili, da je tu, ali ona bi nam na to skrenula pažnju (73-4).

M: Era sveglia anche quand'era proprio piccolissima. Quand'era proprio piccolissima, io e Allie la portavamo con noi al parco. (...) Certe volte ti dimenticavi addiritura che ci fosse, tanto era piccola, ma lei te lo ricordava subito (81). 


\section{Example 2}

ST: "The guys that are on the basketball team stick together, the Catholics stick together, the goddam intellectuals stick together, the boys that play bridge stick together. Even the guys that belong to the goddam Book-of the-Month Club stick together" (118).

M-S: "Fantje, ki igrajo košarko, tišče glave skupaj, katoličani se tišče skupaj, tisti prekleti intelektualci skupaj in fantje, ki igrajo bridž skupaj. Celo fantje, ki so naročeni na knjižne zbirke, tiščijo glave skupaj” (123-4).

J: "Tipi, ki igrajo košarko, tičijo skupaj, katoliki so v drugi klapi, prekleti intelektualci spet posebej, tipi, ki igrajo bridge, spet posebej. Skupaj se družijo celo tipi, ki pripadajo prekletemu klubu Knjiga-meseca" (123).

A: "Tipovi što su u istom košarkaškom timu drže se jedni drugih, katolici se drže jedni drugih, prokleti intelektualci se drže jedni drugih, tipovi što igraju bridž drže se jedni drugih. Čak I oni tipovi iz prokletog kluba pretplatnika na "knjigu meseca" drže se jedni drugih" (137).

M: "Quelli della squadra di pallacanestro fanno lega tra loro, I catolici fanno lega tra loro, I maledetti intelletuali fanno lega tra loro, quelli che giocano a bridge fanno lega tra loro. Fanno lega perfino quelli che appartengono a quel dannato Club del libro del Mese!" (153).

The visibly exaggerated repetitions in the above examples represent a strong stylistic feature of the novel and, apart from expressing Holden's difficulty to communicate, produce a comic effect which should be reproduced in the translation. While $M-S$ shows the tendency to preserve their original impact, J tries to avoid them by the selection of alternative phrases and structures. The loss of this element in the second translation alters the hero's character for, at this point, he does not only seem to have a greater vocabulary, but he also communicates more easily. In this context, the Italian and Serbo-Croatian translations have both successfully reproduced this effect.

(c) Yet another stylistic feature is Holden's use of slang expressions, especially the word 'phony', which is the descriptive leitmotif of the novel according to Newmark $(1988,171)$. Many critics agree that it is the most important word in the novel and speak of 'phoniness' as the generic term that Holden uses to cover all manifestations of hypocrisy in the world around him. Another typical slang expression in Holden's vocabulary is 'sonuvabitch', mostly translated by the two Slovene translators as pasji sin or pesjan, and some variations prokleta strela, pankrt (M-S), putana, and pasji bebec (J). Unlike 'phony', these expressions do not have a particular denotative meaning, they just show Holden's negative attitude towards the world. Apart from prokleta strela which is a rather awkward translation, the two translations retain the negative connotation.

However, the use of slang is not restricted only to particular words and their uses, it can also be found in his frequent repetition of certain expressions as, for example, 'to be killed by', which can mean that he is emotionally affected either favourably (e.g., "Toons. That 
killed me. He meant tombs.", 182) or unfavourably (e.g., "You both have to stay right in position and wait for the orchestra to start playing again. That kills me.", 158). J and A show consistency in the translation of "It killed me." (J: To me je usulo., A: To me je oborilo s nogu.), while $\mathrm{M}-\mathrm{S}$ and $\mathrm{M}$ use a number of alternatives: $\mathrm{M}-\mathrm{S}$ : Bomba!; Zabavalo me je.; To me kar podre.; Uf, me je spodžgala, M: Mi lasciò secco. E fantastica., etc. In both Italian and the first Slovene translation the double meaning of 'kill' is often lost as the above expressions generally refer to either exclusively favourable or unfavourable attitudes. The Italian translation below seems to suggest that Holden is saying the same thing twice, while in the original Holden is aware of the double meaning of 'kill' and feels the need to explain what exactly he has in mind.

ST: She killed Allie, too. I mean he liked her, too ( 61).

M: Allie la trovava fantastica. Piaceva anche a lui, voglio dire /Allie thought she was fantastic. I mean he liked her, too/ (81).

Moreover, while in J's translation to me je usulo retains some characteristics of slang due to its frequency of use, the variants used in M-S's translation lose this feature. Similarly, the exaggerated use of the word 'goddam' is reduced:

ST: "Jane said he was supposed to be a playwright or some goddam thing, but all $I$ ever saw him do was booze all the time and listen to every single goddam mystery program on the radio. And run around the goddam house, naked" (28).

M-S: "Jane je pravila, da je menda dramatik ali nekaj podobnega, toda vsakič, ko sem ga videl, je bil pošteno nadelan in poslušal je vsako kriminalko, ki je bila na radijskem programu, ter letal nag po hiši” (34).

J: “Jane je pravila, da je menda nekakšen dramatik ali kaj jaz vem kakšno prekleto sranje, ampak vse, kar sem jaz videl, je bilo, da se ga je neprenehoma nacejal in poslušal po radiu preklete kriminalke. In se nag podil po tisti prekleti hiši” (33-4).

As already mentioned, Holden is very fond of Jane, so the fact that her stepfather is a 'booze hound' makes him pretty angry, which is stressed by the frequency of his 'goddams'.

(d) Furthermore, Holden's speech blends various levels of diction. On one level, he uses teenage diction, limited vocabulary and violates grammatical rules, particularly in the verb to 'lie' and in the use of the double negative. Costello believes that Holden is correct in many usually difficult expressions (in fact English was the only subject in which he was not failing) and that his grammatical mistakes show that he is a teenager after all.

ST: ...I didn't have hardly any money left... (138).

M-S: ..., ker mi je komaj ostalo še kaj denarja, ... (143).

J: ..., ker mi ni ostalo več dosti denarja... (143).

A: ... jer mi je jedva ostalo nešto malo novca... (159).

$\mathrm{M}$ : ... non avevo quasi più soldi e... (179). 
However, the above translations show no deviation from grammatical correctness. At a slightly more formal level he responds to nuns and waiters. Much more self-consciously he speaks to teachers. Holden is an intelligent, well-read boy and can use, when he wants to, a surprisingly complex word including 'ostracized', 'halitosis', 'bourgeois', and others. Costello points out that much of the humour arises, in fact, from Holden's habit of writing on more than one level at the same time. The examples below show the relative loss of this effect in M-S's translation, as well as J's and A's in the second example.

\section{Example 1}

ST: I have this one stupid aunt with halitosis that... (139).

M-S: In tista moja bedasta teta, ki ji smrdi iz ust, ... (145).

J: Neka prismuknjena teta z ustnim zadahom je... (144).

A: Imam jednu ograničenu tetku što pati od halitozisa, ... (161).

M: Ho quella zia cretina con l'alito cattivo... (181).

\section{Example 2}

ST: She was ostracizing the hell out of me (150).

M-S: Popolnoma me je bojkotirala, prekleto (155).

J: Popolnoma nič ni hotela imeti z mano (155).

A: Nije htela da ima nikakva posla sa mnom (172).

M: Mi stava mettendo al bando con tutti crismi (194).

(e) Newmark points out that letmotifs characterize a character or a situation and that when they are repeated, they should be appropriately foregrounded and repeated in translation. (Newmark 1988, 171) As mentioned above, the most important key word in the novel is 'phony', a slang word which Holden uses to express his negative attitude towards the world, which is full of hypocrites (phonies). Apart from its function as a central lexical unit, the word 'phony' can produce a considerable sound effect to the English speaking person. Its initial sound can be associated with 'phew', an exclamation frequently used for disbelief. It even shares some similarity in sound with 'baloney', a foolish talk or nonsense. The two Slovene translators were faced with the problem of choosing a synonym, not being able to find a Slovene equivalent that would fit the semantic range of 'phony'.

Although lacking the sound characteristics and the frequent use of 'phony', most synonyms used by J (hlimba, hinavski, ponarejen, licemerski, pozerski) more or less embrace the meaning of 'phony'. In M-S's translation only two synonyms with similar meaning can be found, namely lažnivi and zlagano. In most cases, however, $M-S$ translates 'phony' with the noun bedak and its adjectival and adverbial forms bedast, bedasto, which, as a consequence, indicates a complete loss of the leitmotif of the novel. The Serbo-Croatian and Italian translations, but especially the Serbo-Croatian, are both much more successful in this respect for they not only preserve the sound effect of 'phony', but folirant, finto and fasullo can also clearly be perceived as leitmotifs of the novel. 


\begin{tabular}{lccc} 
& fake, not genuine & insincere & pretentious \\
\hline baraba $(M-S)$ & - & - & - \\
\hline hlimba $(J)$ & + & + & $-/(?)+$ \\
\hline prismoda $(M-S)$ & - & - & - \\
\hline bedak $(M-S)$ & - & - & - \\
\hline hinavski $(J)$ & + & + & - \\
\hline afektiran $(J)$ & - & - & + \\
\hline lažnivi $(M-S)$ & + & + & - \\
\hline zlagano $(M-S)$ & + & + & - \\
\hline Puhel $(J)$ & - & - & $(?)+$ \\
\hline smešno $(M-S)$ & - & - & - \\
\hline trapast $(M-S, J)$ & - & - & - \\
\hline ponarejen $(J)$ & + & + & - \\
\hline licemerski $(J)$ & + & + & - \\
\hline sluzast $(J)$ & - & + & + \\
\hline pozerski $(J)$ & + & + & - \\
\hline nagnusni $(M-S)$ & - & - & + \\
\hline folirant $(A)$ & + & + & - \\
\hline Finto $(M)$ & + & + & - \\
\hline fasullo $(M)$ & + & & + \\
\hline
\end{tabular}

\section{Conclusion}

The translator of prose, like the translator of poetry, has the seemingly impossible task to represent the stylistic subtleties of the original. However, to do this the translator has to be aware of the different features of style which characterize a literary work. Bassnett maintains that the central problem for the prose translator is the difficulty of determining translation units (Bassnett 1991, 117). Many stylistic features discussed above could only be recognized as such by taking the whole novel as the prime unit and by considering, above all, the function of both the text and of the devices within the text itself. In this respect it can be argued that, of the four translators, the Serbo-Croatian translator seems to have been the most conscious of the stylistic characteristics of the original.

\section{Bibliography}

Bassnett, S. 1991. Translation Studies. London, New York: Routledge.

Belcher, W. F., and Lee, J. L., eds. 1962. Salinger's Critics. Belmont, California: Wadsworthe Publishing Company.

Galloway, D. D. 1966. The Absurd Hero in American Fiction. Austin and London: University of Texas Press.

Garces, C. V. 1994. A Methodological Proposal for the Assessment of Translated Literary Works: A case study, The Scarlet Letter by N. Hawthorne into Spanish. Revue Babel 40: 77-102.

Grosman, M. 1987. Zakaj se književni prevodi in spremne študije starajo. Delo, 26 February. Književni Listi: 3-4.

and Mozetič, U., eds. 1997. Književni prevod. Ljubljana: Znanstveni inštitut Filozofske fakultete. 
1997. Književni prevod kot oblika medkulturnega posredovanja leposlovja. In Grosman and Mozetič, eds., 11-56.

Hatim, B. 1997. Communication across Cultures: Translation Theory and Contrastive Text Linguistics. Devon: University of Exeter Press.

Mozetič, U. 1997. Problemi prevajanja angleških in ameriških leposlovnih del. In Grosman and Mozetič, eds., 57-74.

Newmark, P. 1988. A Textbook of Translation. Hemel Hempstead: Prentice Hall International (UK).

Nida, E. A., and C. R. Taber. 1982. The Theory and Practice of Translation. Leiden: E. J. Brill.

Salinger, J. D. 1994 (1951). The Catcher in the Rye. London: Penguin.

------. 1961. I/ Giovane Holden. Trans. A. Motti. Torino: Einaudi.

-------. 1966. Igra v rži. Trans. M. Mirtič-Saje. Ljubljana: Mladinska knjiga.

------- 1979. Lovac u raZ̃rans. D. Andrić. Beograd: Rad.

-------. 1990. Varuh mlade rži. Trans. B. Jukić. Ljubljana: Mladinska knjiga. 